\title{
Returns to Education in the Russian Federation: Some New Estimates ${ }^{1}$
}

\author{
Ekaterina Melianova ${ }^{1}$, Suhas Parandekar ${ }^{2}$, \\ Harry Anthony Patrinos ${ }^{3}$, Artëm Volgin ${ }^{4}$
}

\author{
1 World Bank, \\ 36/1, Bolshaya Molchanovka st., Moscow, 121069, Russian Federation. \\ E-mail: melianova95@gmail.com \\ 2 World Bank, \\ 1818 H, Street N.W., Washington DC, 20433, USA. \\ E-mail: sparandekar@worldbank.org \\ ${ }^{3}$ World Bank, \\ 1818 H, Street N.W., Washington DC, 20433, USA. \\ E-mail: hpatrinos@worldbank.org \\ 4 World Bank \\ 36/1, Bolshaya Molchanovka st., Moscow, 121069, Russian Federation. \\ E-mail: art.volgin@gmail.com
}

This paper presents new estimates of the returns to education in the Russian Federation using data from 1994 to 2018. Russia is a highly educated country, and the level schooling continues to increase. More than one-third of the labor force possesses a post-secondary qualification. Our analysis confirms previous studies showing a growth in the overall returns to schooling during the post-transition period. Although the returns to schooling increased for a time, they are now much

1 This paper was prepared as part of the World Bank study, Skills and Returns to Education in the Russian Federation (P170978). We are grateful to Renaud Seligman, Fadia Saadah, Dorota Nowak, Cristian Aedo, Ruslan Yemtsov, Husein Abdul-Hamid, Tigran Shmis, Denis Nikolaev, Polina Zavalina, Zhanna Terlyga, Vladimir Gimpelson, Eduardo Velez Bustillo, George Psacharopoulos, Chris Sakellariou and seminar participants in Washington DC and Moscow for useful comments. All remaining errors are our own. The views expressed here are our own and should not be attributed to the World Bank Group.

Ekaterina Melianova - Consultant.

Suhas Parandekar - Senior Economist.

Harry Anthony Patrinos - Practice Manager.

Artëm Volgin - Consultant.

The article was received: 22.04.2021/The article is accepted for publication: 16.09.2021. 
lower than the global average. Private returns to education are three times greater for higher education compared with vocational education, and the returns to education for females are higher than for males. Returns for females show an inverse U-shaped curve over the past two decades. To control for endogeneity, we also present the estimates of the returns to schooling using instrumental variables, namely, parental socio-economic status and regional dummies. The causal estimates present a much higher rate of return, at 14 percent for females and 8 percent for males. Female education is a policy priority and there is a need to investigate the labor market relevance of vocational education. Higher education may have reached an expansion limit, and it may be necessary to investigate options for increasing the productivity of schooling.

Key words: Returns to Education; Russian Federation.

JEL Classification: I26, I28, J16.

DOI: $10.17323 / 1813-8691-2021-25-3-403-422$

For citation: Melianova E., Parandekar S., Patrinos H.A., Volgin A. Returns to Education in the Russian Federation: Some New Estimates. HSE Economic Journal. 2021; 25(3): 403-422.

\section{Introduction}

"How Wealthy Is Russia?" is a recently published World Bank report that analyzed the human, natural, and produced capital of the Russian Federation [Naikal et al., 2019]. Human capital only accounts for 46 percent of total wealth in Russia, as compared to the OECD average of 70 percent. The report showed that even as growth rates of per capita wealth were 10 times higher in Russia as compared to the OECD, the gap in levels compared with the OECD is still very wide. The per capita human capital wealth level on average for the OECD in 2014 was about $\$ 500,000$ - five times that of Russia's $\$ 95,000$ (measured in 2014 dollars). In order to catch up with the OECD, the returns to education in Russia will need to be increased.

Human capital, or the stock of skills that is possessed by the labor force, is pivotal in enabling countries and individuals to flourish in a multifaceted, increasingly comprehensive, interrelated, and rapidly changing society [Becker, 2009; Broecke, 2015; Heckman, Lochner, Todd, 2003; Mincer, 1974; Schultz, 1972]. The returns to investment in education have been a popular subject of empirical analysis in research to study the relationship between schooling and earnings. Private returns can also explain the private demand for education. The literature suggests that each additional year of schooling produces a private (that is, individual) rate of return to schooling of about 8 to 9 percent a year [Montenegro, Patrinos, 2014; Psacharopoulos, Patrinos, 2018]. Globally, the returns are highest at the tertiary education level, followed by primary and then secondary schooling. This represents a significant reversal from the results of prior studies. Policy makers can learn much from Mincerian results; for instance, further expansion of university education still appears to be worthwhile for the individual even as access to university education has increased dramatically in the past two decades.

Figure 1 indicates the educational attainment of the population aged 25 to 54 years. Less than 14 percent of the labor force has a secondary general education (academic high school); 
the main choice is between vocational education (45 percent) and university education (40 percent). It is well-known that Russian secondary school students perform at par with OECD students in terms of cognitive achievement (PISA scores around 500, the OECD average). What happens after secondary education and in the labor market are crucial issues for convergence with OECD on human capital wealth levels.

\section{Number of People in Russia Aged 25-54 by Achieved Level of Education (per 1000 and an absolute number)}

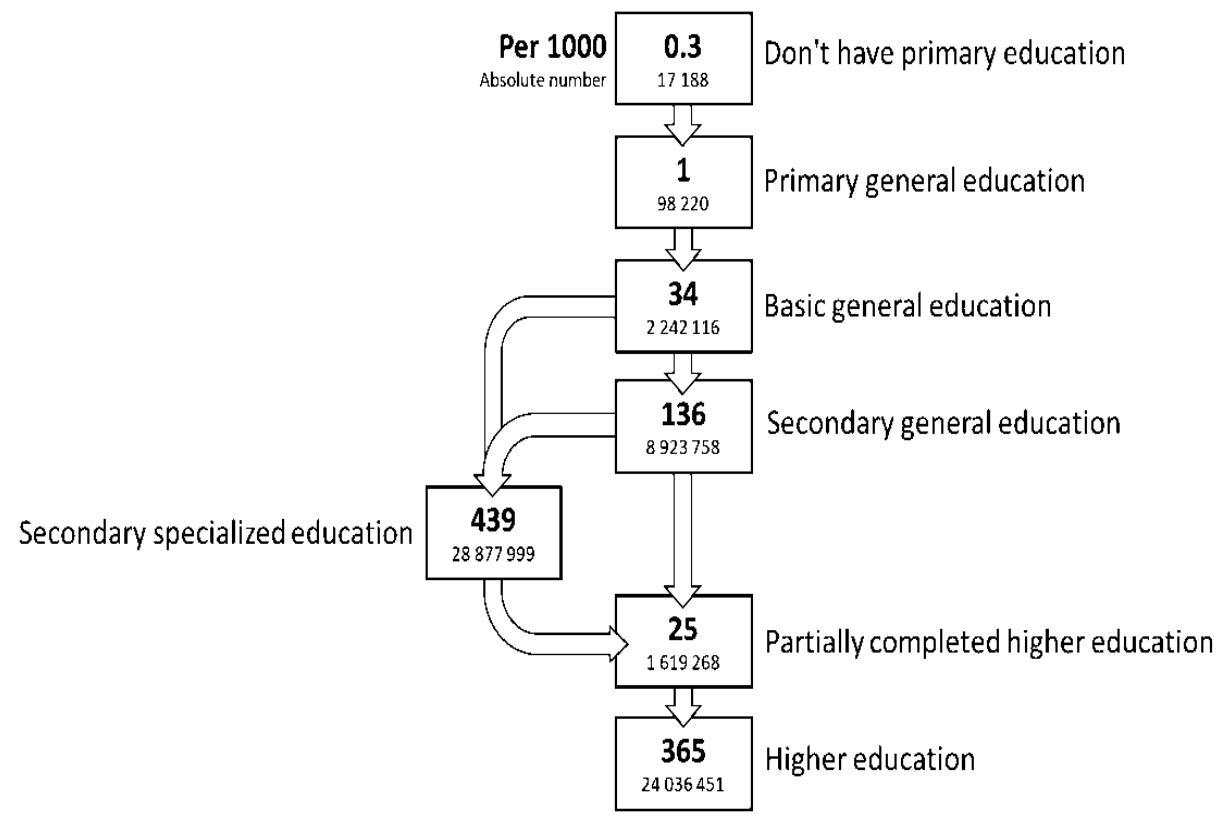

Source: Rosstat.

Fig. 1. Labor Force Distribution by Education Level

In this paper we report on over-time private rates of return to investment in education in the Russian Federation. We examine the trends in returns to education in the Russian Federation using a common methodology used for more than 100 countries [Montenegro, Patrinos, 2014; Psacharopoulos, Patrinos, 2018]. Using standard regression techniques, we find that the returns to education in Russia increased between 1996 and 2003 and then declined thereafter. They reach a high of 9.1 percent in 2001. By 2018, they fall to 5.4 percent. The average returns for the entire period are 7.3 percent, but only 6.3 percent in the last 10 years, among the lowest worldwide and comparable to those estimated using Russian data from the early 1990s.

We find that private returns to education are three times greater for higher education compared to vocational education. The returns to higher education peak at 18 percent. By 2018 they settle at 8 percent, which is just below the European Union average of 10 percent and well below the global average of 15 percent [Psacharopoulos, Patrinos, 2018]. The returns show a 
declining trend in recent years, in line with the expansion in access that took place up to 2009. Higher education may have reached an expansion limit and it may be necessary to investigate options for increasing the productivity of schooling.

The returns to education are higher for females than for males. Returns for females show an inverse U-shaped curve over the past two decades. Women receive much higher returns, averaging above 10 percent during the first few years of the new century. They decline after that, and are approaching convergence with men's returns, but are still significantly higher. We acknowledge the possible endogeneity of the schooling measure and instrument it appropriately. This gives a higher return to female education, but almost no change for men. On average, in Russia, an additional year of education provides a relatively small - and declining - increase in wages.

In the next section we provide a brief overview of the literature with a focus on Russia. Section 3 describes and analyzes the RLMS data used in this study. Section 4 presents the empirical results and Section 5 offers some conclusions.

\section{Literature Review}

In a worldwide perspective, the latest findings on returns to education can be condensed to the following [Psacharopoulos, Patrinos, 2018]: (1) overall, an increased share of workers with tertiary education in the labor market has not reduced the magnitude of returns on the investment due to "skill-biasedness" of technological progress boosting the demand for higher skills; (2) low- and middle-income regions are characterized by the largest returns (except for the Middle East and North Africa, with the lowest returns); (3) the private returns to education for women outstrip those for men by roughly two percentage points; (4) private sector employees receive greater returns than those working in the public sector; (5) social returns to education are negatively associated with a country's level of economic development and education level; and (6) on average, there is a growing trend in returns to higher education.

A small corpus of the research on returns to education has focused on the Russian/USSR case. In the USSR, during the period before education reforms, the private rate of return to schooling was strikingly low: 2-3 percent for secondary and 5 percent for higher education levels [Graeser, 1988]. Low returns to human capital were in line with a planned economy offering free education, centralized allocation of labor, and the ideology of the dictatorship of the proletariat; a similar picture was observed in other contemporaneous socialist countries (see, for example: [Münich, Svejnar, Terrell, 2005]).

However, an even earlier attempt to establish the contribution of education to productivity took place during early Soviet times. Strumilin (1924) showed that those who were more educated contributed more in terms of productivity. He even calculated earnings benefits, and though his calculations did not discount earnings, the estimates of educational returns were high, at about 17 percent in 1919 [Strumilin, 1924].

Within the first two decades of the collapse of the Soviet Union, a group of scholars reported that during the transition period from a planned to market economy in Russia rates of returns to schooling rose sharply [Brainerd, 1998; Clark, 2003; Vernon, 2002; Akhmedjonov, 2014]. The upsurge in wage premiums to education (especially university education) was asserted to be a pivotal factor that exacerbated wage dispersion: salaries of highly skilled and trained workers had increased in absolute terms and compared to less-educated workers [Fleisher, Sabirianova, 
Wang, 2005]. However, returns to schooling declined for those people who took advantage of higher education expansion in a post-communist Russia (1990-2005) in comparison to youths who obtained university degrees in the preceding periods [Kyui, 2016]. One researcher exploited data about the average education level at the end of a Soviet period as an instrument and inferred that the growth in the proportion of city dwellers with university degrees was associated with a rise in the wages of city residents [Muravyev, 2008]. Despite increases in premiums to professional and higher education in the Russian Federation at the beginning of the 2000s, the labor market was shown to be different from that of developed countries. Comparing Russia with France, a researcher demonstrated the existence of a vertical education-occupation mismatch in Russia [Kyui, 2010]. A recent paper claims that a horizontal education-job mismatch negatively impacts the earnings of university graduates in all fields except for the lowest-paid ones [Rudakov et al., 2019].

Another stream of research ascertained that during the market transition period, private returns to education in Russia were not rising and remained among the lowest in the world - the so-called educated Russian's curse [Cheidvasser, Benítez-Silva, 2007]. The contradiction of this finding with previous research was explained by the omitted variable bias: past researchers did not account for regional covariates and rural residence, thus overstating the returns. It was highlighted that the excess of well-educated workers seemed to be the main underpinning factor of wage differentials in Russia after the dissolution of the Soviet Union. Subsequently, Calvo et al. (2015) provide evidence of a reduction in skill premiums in Russia during the 2002-2012 period that was claimed to be one of the most relevant underlying forces explaining a deceleration in trends of widening wage inequality [Calvo et al., 2015]. Belskaya, Peter and Posso (2020) evaluated a large-scale college expansion in Russia after the breakdown of the Soviet Union. Among the key conclusions is that as the number of university campuses grew, individuals with low returns to schooling grew as well. But for a marginal person, who switched into a treatment group as a result of new campuses opening, the total gains from attending a college are considerable and positive. Furthermore, the scholars found that students with higher returns are attracted more intensively by new campuses opened in constrained municipalities (small noncapital cities or those lacking higher education institutions before college expansion) in comparison to the unconstrained ones.

In line with global patterns, studies in Russia have shown that in the post-Soviet decade, workers hired in firms controlled/owned by private organizations/individuals, retained a marked premium to education in contrast to workers employed in state companies. This is rooted in a greater flexibility of private firms, enabling them to overcome restrictions caused by the rigidity of state wages, hence leading to higher returns to schooling [Clark, 2003]. Borisov (2007) was among the first who employed cohort analysis, using a Mincerian wage equation with Russian data, and found evidence favoring the existence of a powerful vintage effect (especially for men) in the Russian labor market during the transition period: consecutive cohorts were paid more than the previous ones, keeping educational achievements constant; this phenomenon was entrenched in the specificity of the Soviet system, encouraging the pursuit of communist interests through extensive propaganda. A source of heterogeneity in rates of returns to education in Russia hails from gender differences, just like the patterns observed globally: women received higher returns to higher education than men (see, for example: [Cheidvasser, Benítez-Silva, 2007; Lukyanova, 2010]). 
By the end of the first decade of the $21^{\text {st }}$ century, some scholars detected positive changes concerning tertiary education in Russia (and other BRIC countries): payoff rates to university completion have generally magnified relative to the rates in lower levels of education and were higher than returns to secondary schooling [Carnoy et al., 2012]. Private rates of return in Russia, even accounting for privately incurred tuition cost, are especially high in business/economics as a field of study [Carnoy et al., 2012]. Additionally, rates of returns to vocational education were found to be lower than payoffs to tertiary education [Borisov, 2007]. In a recent paper, Gimpelson (2019) argues that the labor market in Russia might be at risk of over-education, which leads to a reduction in educational premiums.

An excellent recent paper [Kapeliushnikov, 2021] utilizes alternative surveys in addition to the RLMS to provide a range of estimates on the returns to education. Kapeliushnikov (2021) reports higher estimates and does not find a pattern of an increase followed by a decline of returns from the alternative surveys, though he also has similar findings as reported here when using the RLMS data. Kapeliushnikov (2021) uses four alternative surveys, though none of the surveys covers the same range of time from 1994 to 2018. The four alternative surveys used by Kapeliushnikov (2021) include the Survey of Income and Program Participation from Rosstat (VNDN in the Cyrillic Acronym) available for the years 2011-2018; the Occupational Wage Survey run by Rosstat (OZPP), available for odd years between 2005 and 2019; a one-time household survey carried out in 2003 (NOBUS); and VNECFV, a time-use survey of households. Of the alternatives, the viable comparisons with the RLMS are the Occupational Wage Survey (OZPP) and the Rosstat Household Survey (VNDN). The OZPP samples enterprises rather than households, and includes only employees who are working in medium or large enterprises (excludes self-employed earners as well as small enterprises defined as those with less than 15 workers); the OZPP also excludes certain sectors (for example agriculture, finance, public administration). The OZPP is thus representative of 40 percent of the Russian labor force. The main empirical question here is the extent to which earnings vary between the included and excluded groups in OZPP. Future research can potentially correct for these selection factors in samples where both groups are present and estimate the returns for the restricted group. It is quite possible that returns to education are higher for the included group because of the selection effects, but it is an empirical question. The difference between the RLMS and VNDN is more difficult to explain. The VNDN uses sampling weights where some of the observations carry weights that are orders of magnitudes higher than others - one possible exploration is to determine the effect of excluding the observations with outlier weights to examine the impact of those observation on the overall estimates. Even with the well-acknowledged limitations of the RLMS data, one of its main advantages is the comparability of the household samples and specification with similar international surveys. However, closer examination of within-country variability with larger household surveys such as the VNDN can only add to our growing knowledge of the returns to education in the Russian Federation.

\section{Data and Methodology}

In this paper we use the Russian Longitudinal Monitoring Survey (RLMS) - the only representative Russian household survey with a sizable panel component allowing for dynamic analysis [Kozyreva, Kosolapov, Popkin, 2016]. The data are notable for their reliability, diversity, and applicability to a variety of research questions. The RLMS collects information on people's in- 
come and expenditures, educational and occupational behavior, and a range of other variables. RLMS sampling procedures have been thoroughly and extensively described elsewhere [Kozyreva et al., 2016]. The present research uses all 23 waves (1994-2018) that were available as of June 1,2020. Two years (1997 and 1999) are missing in the data because data were not collected in those years due to funding problems. The sub-sample selected for empirical investigation in this paper consists of working individuals aged 25-64 who are out of school and have positive labor market experience and income.

Table 1 shows descriptive statistics for the key variables under focus and sample sizes by years. The mean of years of potential experience is relatively stable over time and the mean of years of education is observed to increase over time. The increase in mean years of education is matched by the increasing proportion of those graduating from higher education, shown in the last column. Average years of schooling increased from 12.4 to 13.3 years between 1994 and 2018, but the proportion of the labor force with higher education increased 26 to 41 percent, or by 59 percent.

Table 1.

Descriptive Statistics

\begin{tabular}{|c|c|c|c|c|c|c|c|c|c|c|}
\hline \multirow[t]{3}{*}{ Year } & \multirow[t]{3}{*}{$\mathrm{N}$} & \multirow{2}{*}{\multicolumn{2}{|c|}{$\begin{array}{l}\text { Wage (rubles } \\
\text { current) }\end{array}$}} & \multirow{2}{*}{\multicolumn{2}{|c|}{$\begin{array}{c}\text { Experience } \\
\text { (years) }\end{array}$}} & \multirow{2}{*}{\multicolumn{2}{|c|}{$\begin{array}{c}\text { Education } \\
\text { (years) }\end{array}$}} & \multicolumn{3}{|c|}{ Level of Education, (\%) } \\
\hline & & & & & & & & \multirow{2}{*}{$\begin{array}{c}\text { Secondary } \\
\text { Percent }\end{array}$} & \multirow{2}{*}{\begin{tabular}{|c|} 
Vocational \\
Percent \\
\end{tabular}} & \multirow{2}{*}{$\begin{array}{l}\text { Higher } \\
\text { Percent }\end{array}$} \\
\hline & & Mean & SD & Mean & SD & Mean & SD & & & \\
\hline 1994 & 3204 & 266012 & 339748 & 22.5 & 10.6 & 12.4 & 2.7 & 21.3 & 47.8 & 25.9 \\
\hline 1995 & 2792 & 546812 & 613490 & 22.5 & 10.4 & 12.5 & 2.5 & 21.5 & 46.1 & 28.8 \\
\hline 1996 & 2355 & 803429 & 993793 & 22.3 & 10.3 & 12.6 & 2.5 & 19.2 & 47.1 & 30.7 \\
\hline 1998 & 3186 & 895 & 943 & 22.9 & 10.2 & 12.5 & 2.4 & 19.3 & 50.7 & 27.6 \\
\hline 2000 & 3282 & 1808 & 2550 & 22.7 & 10.3 & 12.6 & 2.3 & 19.9 & 50.3 & 27.9 \\
\hline 2001 & 3659 & 2664 & 2839 & 22.3 & 10.1 & 12.7 & 2.3 & 19.5 & 48.6 & 30.6 \\
\hline 2002 & 3853 & 3596 & 4299 & 22.3 & 10.2 & 12.7 & 2.2 & 19.1 & 49.3 & 30.5 \\
\hline 2003 & 3900 & 4355 & 4003 & 22.3 & 10.2 & 12.8 & 2.2 & 18.9 & 49.0 & 31.3 \\
\hline 2004 & 3994 & 5361 & 4913 & 22.1 & 10.3 & 12.8 & 2.2 & 18.3 & 50.1 & 31.0 \\
\hline 2005 & 3937 & 6624 & 5715 & 22.2 & 10.5 & 12.8 & 2.2 & 18.3 & 49.4 & 31.9 \\
\hline 2006 & 4837 & 8081 & 6577 & 22.3 & 10.5 & 12.8 & 2.3 & 17.9 & 50.7 & 30.9 \\
\hline 2007 & 4766 & 9655 & 7129 & 22.5 & 10.6 & 12.8 & 2.3 & 18.4 & 49.9 & 31.3 \\
\hline 2008 & 4844 & 12788 & 10767 & 22.6 & 10.8 & 12.9 & 2.3 & 17.8 & 47.7 & 34.2 \\
\hline 2009 & 4818 & 13344 & 10409 & 22.5 & 11.0 & 12.9 & 2.3 & 16.6 & 47.7 & 35.5 \\
\hline 2010 & 7360 & 14743 & 12579 & 22.6 & 11.1 & 13.0 & 2.3 & 16.9 & 48.0 & 34.9 \\
\hline 2011 & 7197 & 16190 & 12853 & 22.5 & 11.1 & 13.0 & 2.3 & 17.9 & 46.8 & 35.1 \\
\hline 2012 & 7461 & 18844 & 15104 & 22.5 & 11.2 & 12.9 & 2.4 & 18.2 & 45.8 & 35.8 \\
\hline 2013 & 7346 & 20567 & 16404 & 22.5 & 11.2 & 13.0 & 2.3 & 17.0 & 46.7 & 36.1 \\
\hline 2014 & 6161 & 22734 & 17280 & 22.3 & 11.1 & 13.1 & 2.3 & 16.5 & 45.7 & 37.6 \\
\hline 2015 & 6236 & 23532 & 16966 & 22.2 & 11.2 & 13.2 & 2.3 & 15.2 & 44.4 & 40.3 \\
\hline 2016 & 6313 & 24899 & 18634 & 22.3 & 11.1 & 13.3 & 2.3 & 14.6 & 43.6 & 41.7 \\
\hline 2017 & 6375 & 26226 & 19542 & 22.4 & 11.0 & 13.2 & 2.3 & 14.0 & 45.0 & 40.9 \\
\hline 2018 & 6129 & 28081 & 19728 & 22.5 & 10.8 & 13.3 & 2.3 & 13.8 & 45.0 & 41.1 \\
\hline
\end{tabular}

Source: RLMS. 
The Mincer equation, arguably the most widely used in empirical work, can be used to explain a host of economic phenomena. One such application involves explaining (and estimating) wage earnings as a function of schooling and labor market experience. The Mincer equation provides an estimate of the average monetary returns of one additional year of education. This information is important for policy makers who must decide on education spending, prioritization of schooling levels, and education financing programs such as student loans [Patrinos, 2016].

The empirical analysis in this paper presents results for the general working population of the Russian Federation aged 25-64. We use a basic Mincerian specification shown in equation (1):

$$
\log (\text { Wage })=b_{0}+b_{1} \cdot E d u c+b_{2} \cdot \operatorname{Exp}+b_{3} \cdot \operatorname{Exp}^{2}+\varepsilon
$$

where $\log ($ Wage $)$ is a logarithm of monthly wage, Educ stands for the years of education or highest attained level of education, $\operatorname{Exp}$ and $\operatorname{Exp}^{2}$ reflect the years of working experience and its quadratic term respectively, $b_{0}$ is an intercept, $b_{1} \ldots b_{n}$ are the respective slope estimates, $\varepsilon$ refers to a normally distributed error term.

Dependent variable. For the dependent variable, we use the logarithm of the average monthly wage within the past year from a person's primary job (variable $j 13.2$ in the RLMS data set). If a person had an additional job, the maximum wage value among the two (variables $j 13.2$ and j40) was selected for the analysis. In the waves from 1994 to 1996, the question mentioned above was absent; for those waves, we exploited a variable about the average amount of money earned by a respondent within the past 30 days (variable $j 10$ ) as a reasonable approximation.

Independent variables. The present research uses both metric (measured in years) and categorical education variables. The metric version was created by assigning the average expected number of years corresponding to each attained education level. For the categorical version (EDUC), we distinguished three categories: (1) secondary, (2) vocational and (3) higher. Incomplete levels were incorporated into the respective upper categories (e.g., incomplete higher into higher). Vocational education here includes the International Standard Classification of Education (ISCED) levels for vocational education: 35,45 and $55^{2}$. We are interested in exploring returns to education in general, and vocational and higher education. Estimations of premiums to primary and secondary schooling levels are technically not possible since there is a minuscule proportion of people with only primary education or lower. The experience variable was calculated as a potential experience, subtracting from the current age the years of education minus $\varepsilon$ (the typical school starting age). Regression (1) was estimated separately for each year for the entire sample and separately for males and females. The Appendix ${ }^{3}$ (Tables A1 to A23) presents the results for each year.

We are particularly interested in the returns to specific levels of education, estimated through a series of dummy variables. Using Secondary Education completed as the base or omit-

\footnotetext{
2 The ISCED classification as it is applied to the Russian Federation is graphically explained in the OECD online publication accessible at https://gpseducation.oecd.org/CountryProfile?primaryCountry=RUS

${ }^{3}$ See on the website: https://ej.hse.ru/data/2021/appendix.pdf
} 
ted dummy for purposes of interpretation, we use dummy variables for vocational and higher education. The specification is presented in equation (2):

$$
\log (\text { Wage })=a_{0}+a_{1} \cdot D_{\text {Voc }}+a_{2} \cdot D_{\text {Higher }}+a_{3} \cdot \operatorname{Exp}+a_{4} \cdot \operatorname{Exp}^{2}+\varepsilon
$$

\section{Results}

Results of equation (1) for the whole sample are shown in Fig. 2 with an adjoining graph showing the increase in the mean years of education over the period 1994 to 2018 . Returns by each year in the Russian Federation need to be considered carefully because of the high educational attainment of the population. There are hardly any individuals in the sample who have less than a high school education (precisely 35 of 1,000 as shown in Fig. 1), and only a handful of individuals who finished their education at the high school level. Consequently, the mean education is more than 13 years.

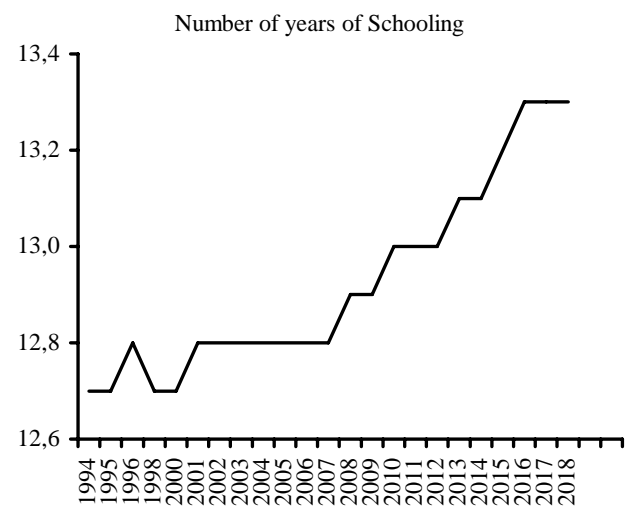

Source: Rosstat.

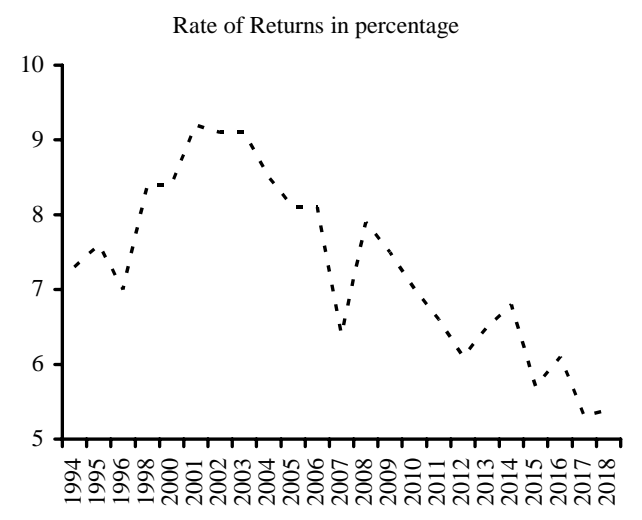

Source: RLMS.

Fig. 2. Labor Force Distribution by Educational Level

Figure 3 demonstrates the earnings ratio by educational level (secondary education is equal to 100 percent) for 1998,2006 , and 2018. Each panel in the graph depicts a pronounced gap in the wages of people with secondary or vocational education compared to those with university level especially in earlier years in Russia.

Figure 4 displays age-earning profiles in Russia by education level. There is a concave pattern for individuals with higher education, whereas for secondary and vocational levels, the association between wages and age is almost flat or descending. Figure 5 depicts the estimates of equation (1) for the whole sample compared with sub-samples by gender for the period 19942018: the percentage increment in a person's earnings due to one additional year of schooling. Overall, one can notice a moderate curved growth in returns to education in Russia, achieving its peak in the early 2000s (returns of 9.8 percent), which is followed by a downward pattern (returns of 5.6 percent by 2018). The values of returns to schooling in recent years in Russia seem to lag far behind the global average of 9.5 percent [Psacharopoulos, Patrinos, 2018]. Education payoffs for women are higher than those of men, but the difference appears to have narrowed slightly in recent years. 

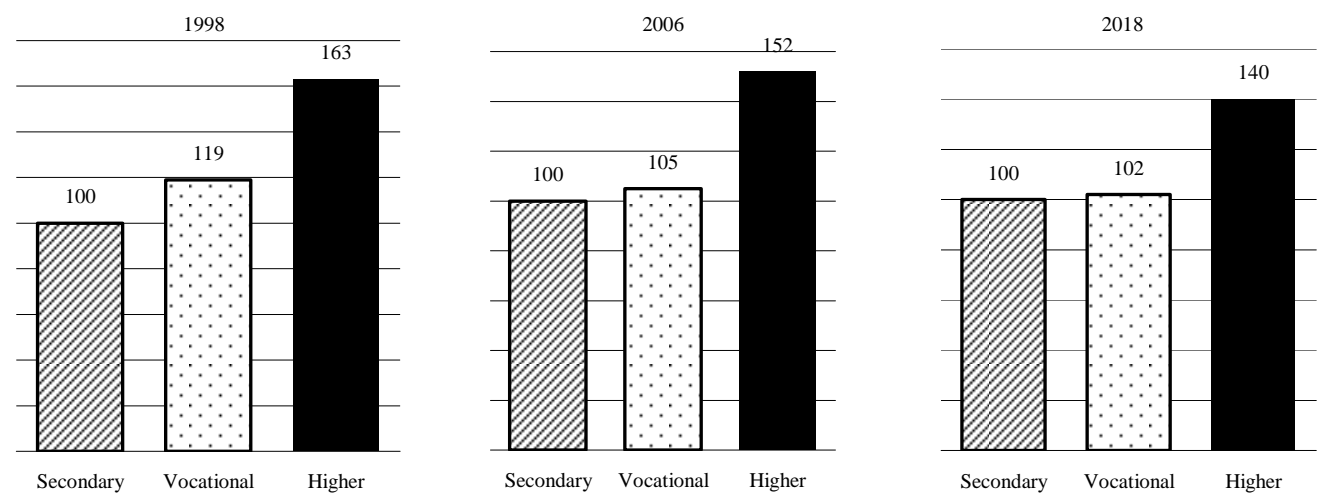

Source: RLMS.

Fig. 3. Earnings Ratio by Educational Level $($ Secondary Education $=100 \%)$
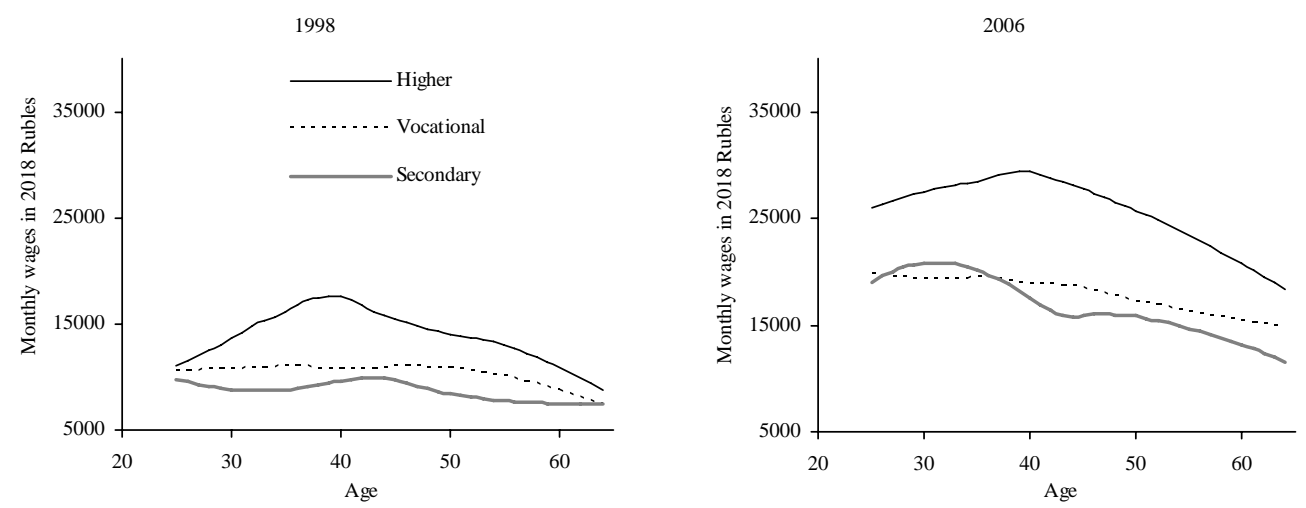

2018

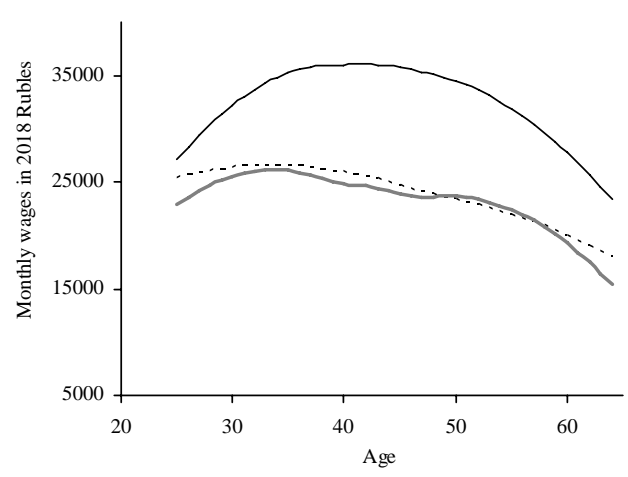

Source: RLMS.

Fig. 4. Age-earning Profiles by Level of Education 


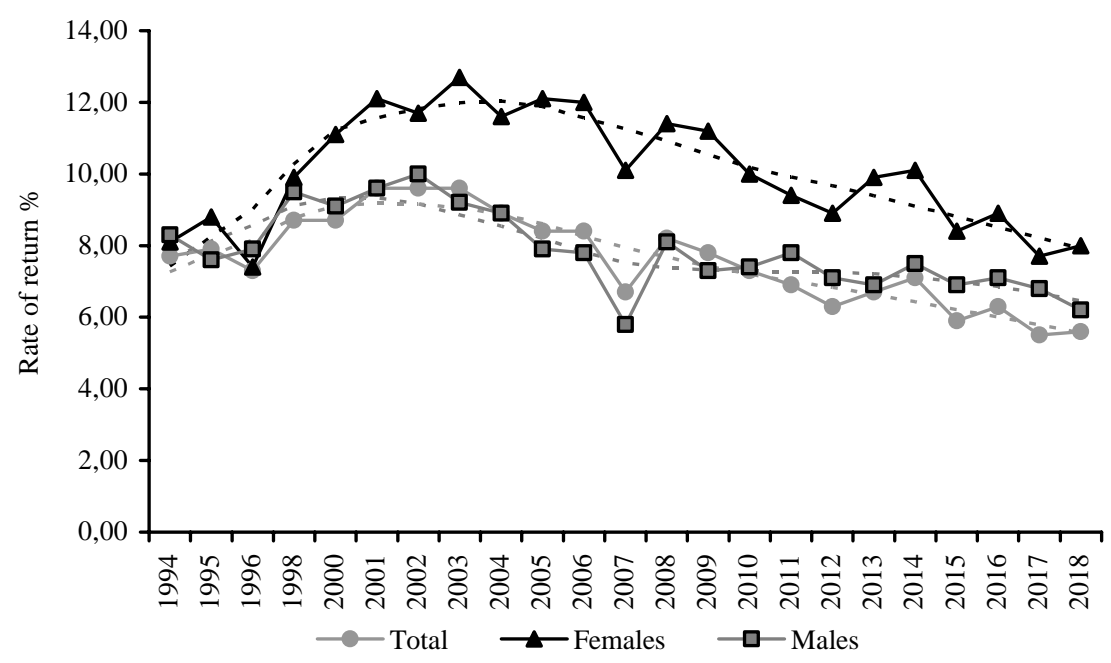

Source: RLMS 1994-2018.

Fig. 5. Rates of Returns to Education in Russia

Figure 6 panel (a) displays the results of estimating equation (2) - the rates of returns to higher and vocational education (as compared to secondary education) in Russia for the period 1994-2018. The figure shows wage premiums to university education in Russia that are 3-5 times greater than vocational education. The observed trend for premiums to both vocational and higher education levels shows a peak of 18 percent per year for higher education and 6 percent a year for vocational education compared to the average earnings of workers with a secondary education. The interesting pattern to note from Figure $6 \mathrm{a}$ is the apparent co-movement of vocational education and higher education - the higher education smoothing curve turns a bit more sharply than the one for vocational education, but their movement is matching, even at second-order levels of smoothness. Even though the higher education premium remains above the premium for vocational education, there is a perceptible narrowing of the difference in recent years. Panel 6.4b, which is drawn from Telezhkina (2019), shows the interesting pattern of higher education enrollment rates for the population ages 17-25 years. Figure $6 \mathrm{~b}$ shows the downturn in returns reflected in enrollments, with the peak in enrollments coming about 10 years later. The latest estimate of the returns to higher education in the Russian Federation is about 8 percent, which is just below the EU average of about 10 percent and the global average of 15 percent [Psacharopoulos, Patrinos, 2018]. The returns show a declining trend in recent years, in line with the expansion in access that took place up to 2009.

Estimation separately by sub-samples of gender shows a variation in the trends. Annual returns to higher education for males declined from 15 to 9 percent, whereas women's returns are described by an inversely U-shaped pattern, reaching their maximum of 28 percent in 2003. Within roughly the last 5 years, wage premiums to higher education for women have stabilized at around 12 percent, a couple of percentage points ahead of men. Gender-wise enrollment rates in higher education (not shown) 10 years later appear to match the differences in rates of return, strengthening the hypothesis that market rates of return to education in Russia do indeed influence individual continuing school decisions. 


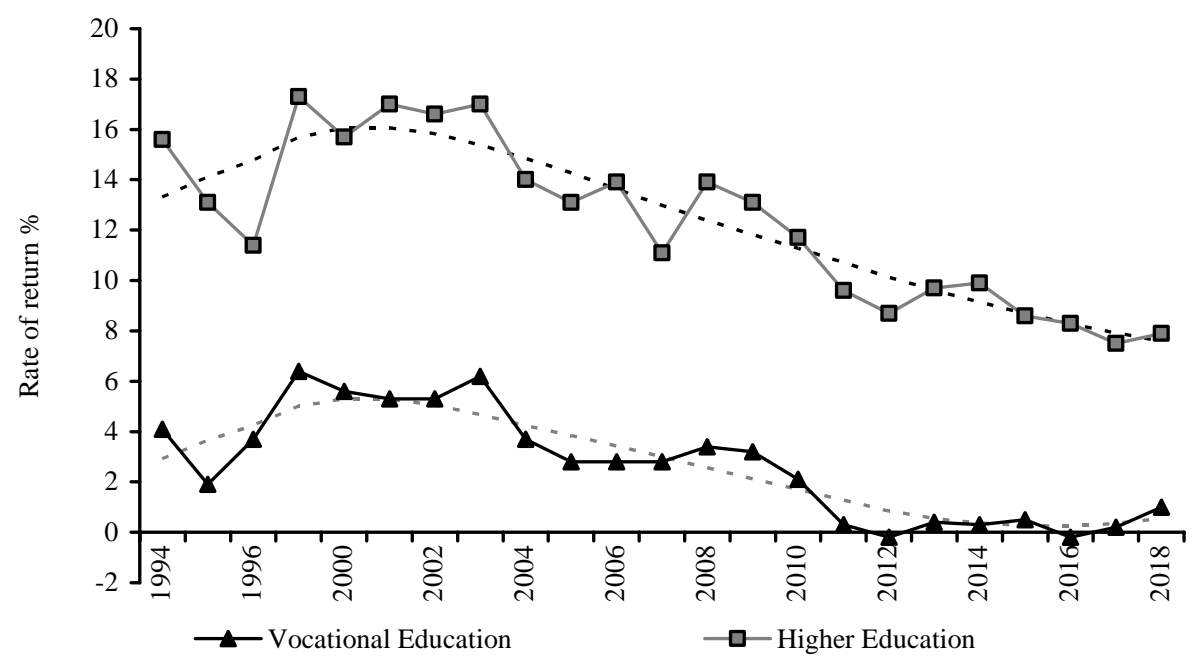

Source: RLMS 1994-2018.

(a) Rates of Return

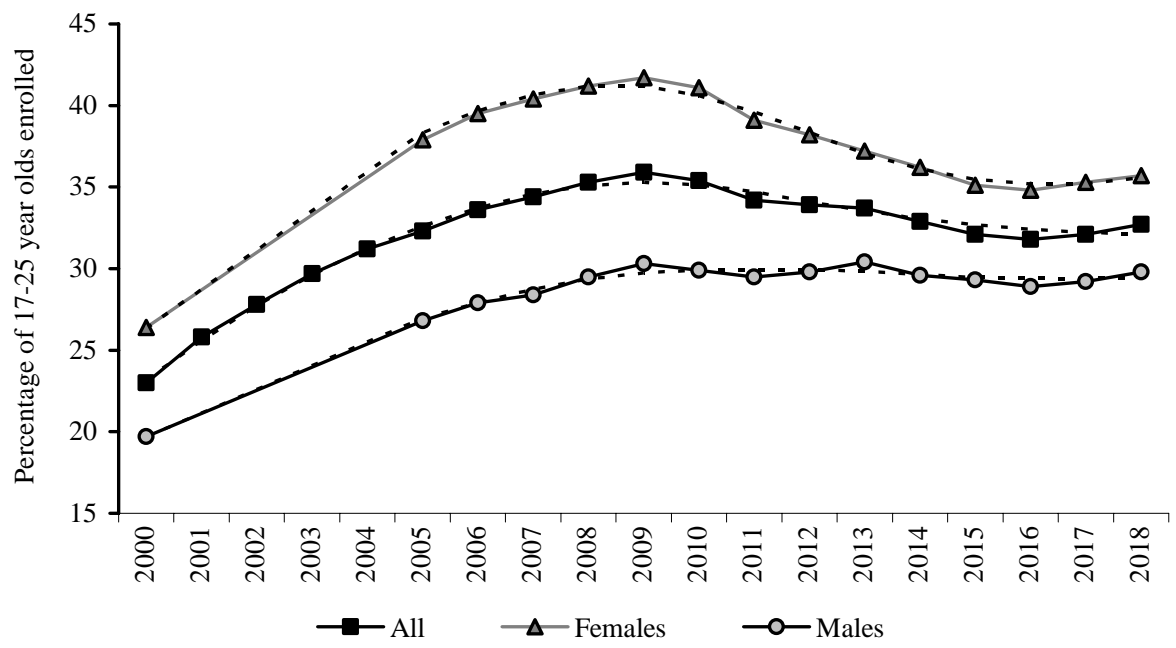

(b) Enrollment in Higher Education

Source: Telezkhina, 2019; HSE Education Year Book.

Fig. 6. Rates of Returns to Higher and Vocational Education in Russia, 1994-2018

A similar comparative picture is observed with respect to vocational education, albeit with a different kind of variation by gender (see Fig. 7): returns for males are almost flat within the time period while returns for females shows a concave pattern. The overall outcome concerning payoffs to schooling isolated by gender has been confirmed in a similar fashion by past studies (see, for example: [Cheidvasser, Benítez-Silva, 2007]). 


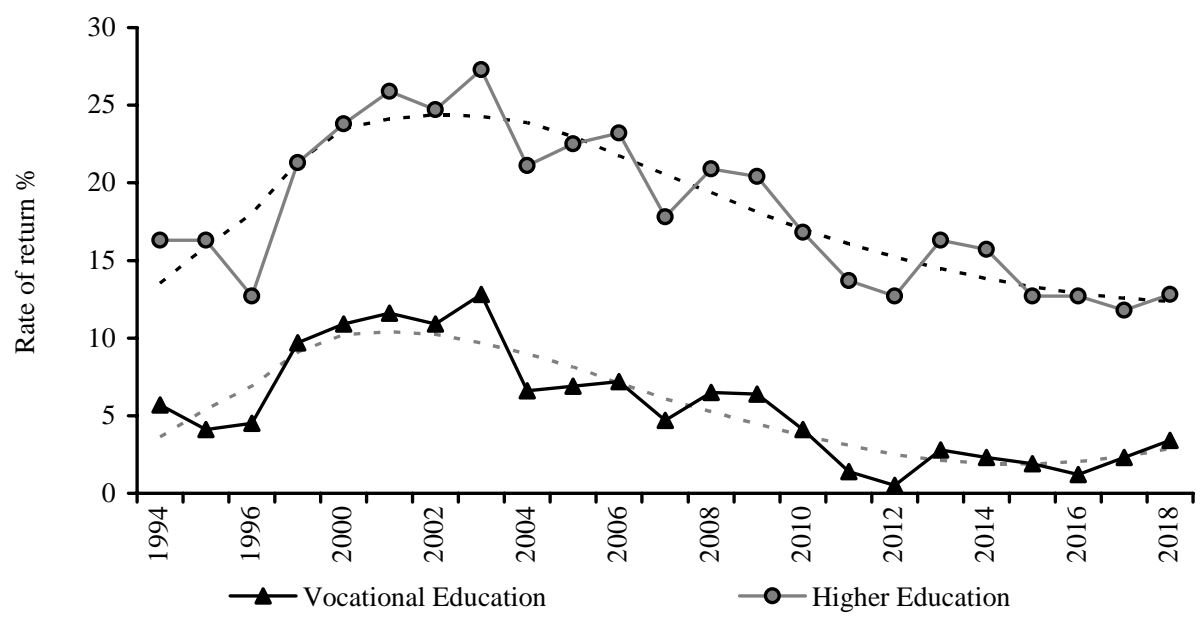

(a) Females

Source: RLMS 1994-2018.

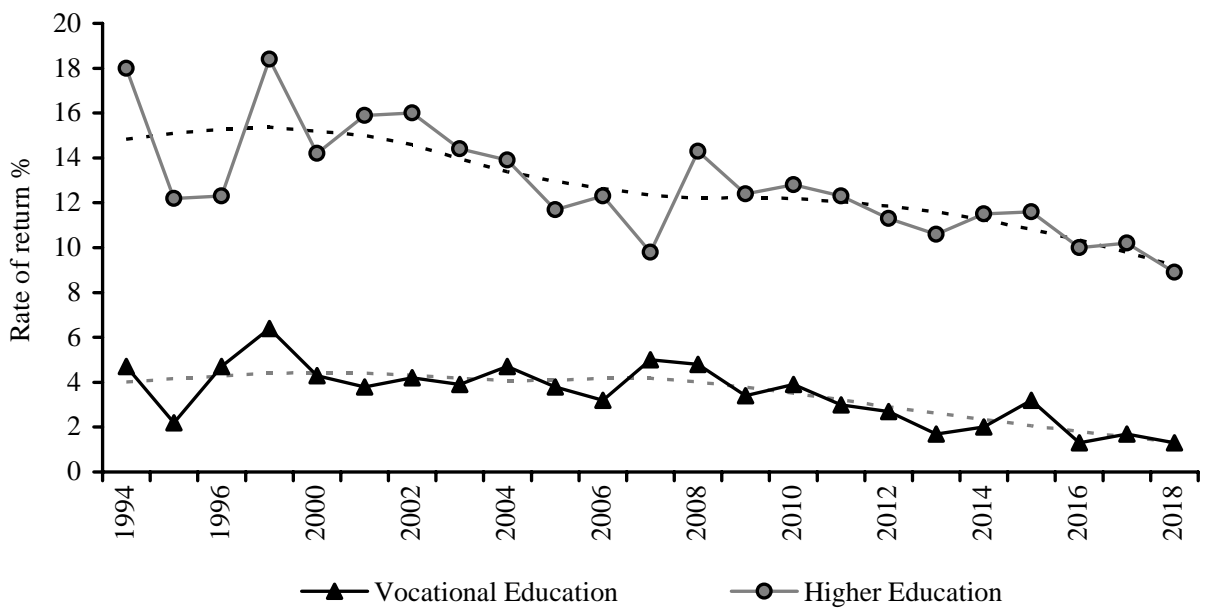

Source: RLMS 1994-2018.

(b) Males

Fig. 7. Rates of Returns to Higher and Vocational Education in Russia

Instrumental Variable Specification. A sizeable proportion of the earnings literature holds that returns estimated from Ordinary Least Squares (OLS) may be biased due to the possible presence of an omitted variable bias and resulting heterogeneity in the net benefits of additional schooling across individuals. Instrumental variable (IV) regression is a method used to deal with these issues [Card, 1999; Patrinos, Sakellariou, 2005].

As instrumental variables, we use indicators of the Parental Socio-Economic Status (SES) of individuals when the individuals were 15 years old. Even though some authors express the 
opinion that family background related variables may suffer the same problem as an endogenous education variable, variables such as father's education have been used as instruments in earnings functions (see, for example: [Dearden, 1998; Harmon, Walker, 2000; Hoogerheide, Block, Thurik, 2012; Ichino, Winter-Ebmer, 1999; Pons, Gonzalo, 2001]). Parental education can be said to be related to the schooling level of an individual through genetic or environmental effects when an individual is a dependent child in a parent's household. However, the direct influence of parental education on adult earnings, independent of the influence on schooling, would be mild. In such a case it has been shown that the findings would not substantially deviate from the benchmark case of a strictly exogenous instrument.

The current paper exploited retrospective RLMS questions, asked in 2006 and 2011, about mother's and father's occupation (J216AC08, J216BC08), and their highest achieved education level (J217A, J217B) at a respondent's age of 15. Occupational categories were converted to indices with the help of The Standard Occupational Prestige Scale (SIOPS) [Ganzeboom, Treiman, 2019]. The final family background measures represented maximum values for the two SES dimensions between two parents. Besides, following the lead of several past studies [Angrist, Krueger, 1991; Card, 1999; Kim et al., 2019) we make use of dummies for the Russian regions, in which individuals reside at the time of the interview (STATUS), as instruments. The analysis was performed, using 2018 RLMS data to capture the most recent labor market situation.

The general TSLS specification of interest can be written by the following equations.

First stage:

$$
x_{1 i}=z_{i}^{\prime} \pi_{1}+x_{2 i}^{\prime} \pi_{2}+v_{i}
$$

Second stage:

$$
y_{i}=x_{1 i} \beta_{1}+x_{2 i}^{\prime} \beta_{2}+\varepsilon_{i},
$$

where $y$ is a logarithm of wages for $i=1,2, \ldots, N ; x_{1 i}$ reflects years of education (an endogenous regressor); $x_{2 i}$ is a vector of exogenous variables: labor market experience, its squared term, and a binary characteristic for living in urban area; $z_{i}$ is a vector of instrumental variables; $\beta_{1}$ is the causal effect of $x_{1}$ on $y ; \varepsilon_{i}$ and $v_{i}$ are normally distributed error terms.

Table 2 presents the estimated schooling equation for males and females. The results demonstrate that after controlling for the labor market experience, its quadratic term, and type of settlement individuals, whose parents had higher occupational prestige and more completed years of education during his or her adolescence, study longer. Statistically insignificant regional dummies were removed from the models, therefore, only a fraction of regions was specified as instruments. The findings imply that the monotonicity identifying assumption (the absence of defiers) may be satisfied, although, in general, it is considered untestable. Defiers in this case would be children of highly educated parents who get the same education as children of low educated parents and vice-versa. 
Schooling Equations: Russia, 2018

Table 2.

\begin{tabular}{|c|c|c|}
\hline & Females & Males \\
\hline Family occupational prestige & $\begin{array}{r}0.0204 \\
(-6.65)\end{array}$ & $\begin{array}{l}0.0237 \\
(-6.57)\end{array}$ \\
\hline Family education, years & $\begin{array}{r}0.111 \\
(-7.64)\end{array}$ & $\begin{array}{l}0.0823 \\
(-5.01)\end{array}$ \\
\hline Permskiy Krai & $\begin{array}{r}-0.66 \\
(-2.78)\end{array}$ & $\begin{array}{l}-0.891 \\
(-3.72)\end{array}$ \\
\hline Tverskaya Oblast & $\begin{array}{r}-0.56 \\
(-2.31)\end{array}$ & \\
\hline Krasnoyarskiy Kray & $\begin{array}{l}-1.287 \\
(-4.32)\end{array}$ & \\
\hline Rostovskaya Oblast & $\begin{array}{l}-0.825 \\
(-2.74)\end{array}$ & \\
\hline Experience & $\begin{array}{r}-0.12 \\
(-8.13)\end{array}$ & $\begin{array}{l}-0.153 \\
(-7.71)\end{array}$ \\
\hline Experience squared & $\begin{array}{r}0.00129 \\
(-4.34)\end{array}$ & $\begin{array}{r}0.00198 \\
(-5.05)\end{array}$ \\
\hline Urban & $\begin{array}{r}0.52 \\
(-5.43)\end{array}$ & $\begin{array}{r}0.795 \\
(-7.49)\end{array}$ \\
\hline Tambovskaya Oblast & & $\begin{array}{l}-0.923 \\
(-3.92)\end{array}$ \\
\hline Kabardino-Balkarskaya Resp. & & $\begin{array}{l}1.382 \\
(-2.4)\end{array}$ \\
\hline Constant & $\begin{array}{r}13.18 \\
(-55.35)\end{array}$ & $\begin{array}{r}12.74 \\
(-41.77)\end{array}$ \\
\hline$N$ & 2222 & 1694 \\
\hline $\operatorname{adj} R^{2}$ & 0.2266 & 0.2359 \\
\hline F-value & 73.32 & 66.35 \\
\hline
\end{tabular}

Note: $\mathrm{t}$ statistics in parentheses.

Source: RLMS.

The IV estimation results, using the parental SES and regional dummies, are shown in the upper panel of Table 3. The instrumental variable approach yields the rate of returns to education in Russia of around 14.3 percent for females and 8 percent for males. Females' IV parameters appeared to be tangibly larger compared to the respective OLS estimate of 7.6 percent, while for males the IV and OLS ( 6 percent) estimates are much closer in magnitude. The female estimates are in line with what other researchers using instruments find in Russia (see, for example: [Arabsheibani, Staneva, 2012]). 
Returns to Education from Instrumental Variables: Russia, 2018

\begin{tabular}{|c|c|c|}
\hline & Females & Males \\
\hline Education, years & $\begin{array}{r}0.1430 \\
(-8.19)\end{array}$ & $\begin{array}{l}0.0798 \\
(-3.43)\end{array}$ \\
\hline Experience & $\begin{array}{r}0.0313 \\
(-5.65)\end{array}$ & $\begin{array}{r}0.0303 \\
(-4.3)\end{array}$ \\
\hline Experience squared & $\begin{array}{r}-0.0006 \\
(-5.99)\end{array}$ & $\begin{array}{r}-0.0007 \\
(-5.61)\end{array}$ \\
\hline Urban & $\begin{array}{r}0.161 \\
(-5.51)\end{array}$ & $\begin{array}{r}0.18 \\
(-5.69)\end{array}$ \\
\hline Constant & $\begin{array}{r}7.501 \\
(-27.00)\end{array}$ & $\begin{array}{r}8.833 \\
(-26.65)\end{array}$ \\
\hline$N$ & 2222 & 1694 \\
\hline Centered $R^{2}$ & 0.083 & 0.131 \\
\hline (i) Partial $R^{2}$ for excluded instruments in the first stage & 0.105 & 0.093 \\
\hline F-test & 43.63 & 34.43 \\
\hline$p$-value & 0.000 & 0.000 \\
\hline (ii) Pagan-Hall for heteroskedasticity & 5.78 & 9.973 \\
\hline p-value & 0.762 & 0.267 \\
\hline (iii) Kleibergen-Paap rk LM statistic (underidentification test) & 200.607 & 132.985 \\
\hline p-value & 0.000 & 0.000 \\
\hline (iv) Sargan-Hansen J statistic (overidentification test) & 10.395 & 20.158 \\
\hline p-value & 0.065 & 0.0005 \\
\hline (v) Hausman endogeneity test & 17.243 & 1.099 \\
\hline p-value & 0.000 & 0.295 \\
\hline (vi) Cragg-Donald Wald F statistic & 43.279 & 34.399 \\
\hline Stock-Yogo critical values: 5\% maximal IV relative bias & 19.28 & 18.37 \\
\hline Stock-Yogo critical values: $10 \%$ maximal IV size & 29.18 & 26.87 \\
\hline
\end{tabular}

Note: z statistics in parentheses.

Source: RLMS.

To ascertain the statistical validity of the implemented instruments, we conducted an array of diagnostic tests using the Stata command ivreg2. The lower panel of Table 3 shows the results from these tests. The F-test for possibility of weak instruments indicates that the instru- 
ments under focus are not weak; they are strongly correlated with the endogenous regressor. The Pagan-Hall tests indicate that errors are homoscedastic. The Kleibergen-Paap underidentification test further supports the null hypothesis, meaning that the instruments are relevant. The orthogonality of the set of instruments to the error process in the structural equation was checked by the Sargan-Hansen test of overidentifying restrictions; this is statistically significant for males, but for females the $p$-value is 0.065 . The Hausman endogeneity test shows that the education variable may not be endogenous for males ( $p=0.295)$; therefore, there is no advantage to be gained from IV estimation for males, a finding already hinted at from the low difference between OLS and IV estimates for males. Finally, a Stock and Yogo's test points out that even if we are willing to tolerate a 5 percent IV relative bias or 10 percent IV rejection rate at maximum, we can conclude that our instruments are not weak because the Cragg-Donald Wald F for both male and female sub-samples exceeds the corresponding critical values. To summarize, the diagnostics contend that the OLS estimates of returns to schooling for males in the given specification are more preferable over the IV estimates, whereas for females the IV parameters are appropriate.

\section{Conclusions}

Russia is a highly educated country, and the level schooling continues to increase. More than one-third of the labor force possesses a post-secondary qualification. Our analysis confirms previous studies showing a growth in the overall returns to schooling during the post-transition period [Brainerd, 1998; Clark, 2003; Vernon, 2002]. There was an increase in the returns to an additional year of schooling in the 1990s. The returns peaked in the early 2000s (at almost 10 percent) followed by a downward pattern (returns of 5.6 percent by 2018). Note that the global average is about 8-9 percent [Psacharopoulos, Patrinos, 2018]. The extent to which the declines are due to potential "over-education" is worth investigating [Gimpelson, 2019].

Education payoffs for women are higher than those of men, but the difference appears to have narrowed in recent years. The higher returns to education for females is consistent with global findings [Psacharopoulos, Patrinos, 2018] and previous studies of the Russian labor market [Cheidvasser, Benítez-Silva, 2007; Lukyanova, 2010]. When estimated separately by gender, we find trend variation. The results from estimation of earnings functions show that annual returns to higher education for males varied from 9 to 15 percent, whereas women's returns are described by an inverse U-shaped pattern, reaching their maximum of 28 percent in 2003. Within roughly the last five years, wage premiums to higher education for women have stabilized at around 12 percent, a couple of percentage points ahead of men. Gender-wise enrollment rates in higher education 10 years later appear to match the differences in rates of return, strengthening the hypothesis that market rates of return to education in Russia do indeed influence positively the demand for schooling. Just in the past two years, the enrollment decline appears to be slowly reversing, but this phenomenon needs to be watched more closely to determine if it is merely a fluctuation or a new trend.

We show that private returns to education are three times greater for higher education compared to vocational education. On average, wage premiums to university education in Russia are roughly 3-5 times greater than to vocational schooling. This is consistent with findings from global studies and from previous research on the Russian labor market [Borisov, 2007; Carnoy et al., 2012]. Higher education enrollment rates increased substantially after the break-up of the 
Soviet Union [Belskaya, Peter, Posso, 2020]. Enrollments peaked in 2009. Subsequent returns to higher education started to fall relative to secondary education. The latest estimate of the returns to higher education in the Russian Federation is about 8 percent, which is just below the EU average of about 10 percent and the global average of 15 percent [Psacharopoulos, Patrinos, 2018]. But the wage profiles for those with secondary and vocational education are almost flat or descending, while the gaps between higher education and vocational education are increasing, in favor of higher education.

Going forward, several policy options and research priorities are worth mentioning. Female education remains a policy priority as it promotes earnings growth and helps reduce gender gaps in the labor market. Maintaining the high level of participation is warranted, while investigating the declining trends in returns is a research theme for future work. There is a need to investigate the labor market relevance of vocational education given the low and declining returns. Higher education may have reached an expansion limit and it may be necessary to investigate options for increasing the productivity of schooling. Estimates of the social returns to vocational education should be part of the further research agenda. Alternatively, a cost-effectiveness comparing with secondary may give useful information as well.

Future research could also look at the variations in returns across regions. Also, it would be worth looking at alternative labor market sources such as the ones that Kapeliushnikov (2021) explored and to undertake closer examination of within-country variability with larger household surveys such as the VNDN. It would also be useful to estimate social returns to education in order to derive more robust policy recommendations. Finally, further causal estimates of the returns to schooling should be estimated, perhaps using the recent pandemic as an instrument.

$* *$

\section{References}

Akhmedjonov A. (2011) Do Higher Levels of Education Raise Earnings in Post-Reform Russia? Eastern European Economics, 49, 4, pp. 47-60.

Angrist J.D., Krueger A.B. (1991) Does Compulsory School Attendance Affect Schooling and Earnings? The Quarterly Journal of Economics, 106, 4, pp. 979-1014.

Arabsheibani R.G., Staneva A. (2012) Returns to Education in Russia: Where There Is Risky Sexual Behaviour There Is Also an Instrument. Institute of Labor Economics (IZA). IZA Discussion Paper no 6726. Becker G.S. (2009) Human Capital: A Theoretical and Empirical Analysis, with Special Reference to Education. University of Chicago Press.

Belskaya V., Sabirianova Peter K., Posso C.M. (2020) Heterogeneity in the Effect of College Expansion Policy on Wages: Evidence from the Russian Labor Market. Journal of Human Capital, 14, 1, pp. 84-121.

Borisov G. (2007) The Vintage Effect on the Russian Labor Market. Eastern European Economics, 45, 2, pp. 2351.

Brainerd E. (1998) Winners and Losers in Russia's Economic Transition. American Economic Review, 88, 5, pp. 1094-1116.

Broecke S. (2015) Experience and the Returns to Education and Skill in OECD Countries. OECD Journal: Economic Studies, 2015, 1, pp. 123-147. 
Calvo P.A., López-Calva L.F., Posadas J. (2015) A Decade of Declining Earnings Inequality in the Russian Federation. The World Bank.

Card D. (1999) The Causal Effect of Education on Earnings. Handbook of Labor Economics. Vol. 3, Elsevier, pp. 1801-1863.

Carnoy M., Loyalka P.K., Androushchak G.V., Proudnikova A. (2012) The Economic Returns to Higher Education in the BRIC Countries and Their Implications for Higher Education Expansion. Higher School of Economics Research Paper no WP BRP 2.

Cheidvasser S., Benítez-Silva H. (2007) The Educated Russian's Curse: Returns to Education in the Russian Federation during the 1990s. Labour, 21, 1, pp. 1-41.

Clark A. (2003) Returns to Human Capital Investment in a Transition Economy: The Case of Russia, 1994-1998. International Journal of Manpower, 24, 1, pp. 11-30.

Dearden L. (1998) Ability, Families, Education and Earnings in Britain. Institute for Fiscal Studies Working Paper no W98/14.

Fleisher B.M., Sabirianova K., Wang X. (2005) Returns to Skills and the Speed of Reforms: Evidence from Central and Eastern Europe, China, and Russia. Journal of Comparative Economics, 33, 2, pp. 351-370. Ganzeboom H.B.G., Treiman D.J. (2019) International Stratification and Mobility File: Conversion Tools. Amsterdam: Department of Social Research Methodology. Available at: http://www.harryganzeboom.nl/ ismf/index.htm>. [Date of last revision: 2019/10/05]

Gimpelson V. (2019) The Labor Market in Russia, 2000-2017. IZA World of Labor 2019, 466, pp. 1-13. Graeser P. (1988) Human Capital in a Centrally Planned Economy: Evidence. Kyklos, 41, 1, pp. 75-98. Harmon C., Walker I. (2000) Returns to the Quantity and Quality of Education: Evidence for Men in England and Wales. Economica, 67, pp.19-35.

Heckman J.J., Lochner L.J., Todd P.E. (2003) Fifty Years of Mincer Earnings Regressions. National Bureau of Economic Research Working Paper w9732.

Hoogerheide L., Block J.H., Thurik R. (2012) Family Background Variables as Instruments for Education in Income Regressions: A Bayesian Analysis. Economics of Education Review, 31, 5, pp. 515-523.

Ichino A., Winter-Ebmer R. (1999) Lower and Upper Bounds of Returns to Schooling: An Exercise in IV Estimation with Different Instruments. European Economic Review, 43, 4-6, pp. 889-901. Kapeliushnikov R.I. (2021) Returns to Education in Russia: Nowhere Lower? National Research University Higher School of Economics Working Paper WP3/2021/03, Moscow (in Russian). Kim J.S., Jiang B., Li Ch., Yang H.-S. (2019) Returns to Women's Education Using Optimal IV Selection. Applied Economics, 51, 8, pp. 815-830.

Kozyreva P., Kosolapov M., Popkin B.M. (2016) Data Resource Profile: The Russia Longitudinal Monitoring Survey - Higher School of Economics (RLMS-HSE) Phase II: Monitoring the Economic and Health Situation in Russia, 1994-2013. International Journal of Epidemiology, 45, 2, pp. 395-401.

Kyui N. (2010) Returns to Education and Education-Occupation Mismatch within a Transition Economy. Empirical Analysis for the Russian Federation. Université Panthéon-Sorbonne (Paris 1), Centre d'Economie de la Sorbonne.

Kyui N. (2016) Expansion of Higher Education, Employment and Wages: Evidence from the Russian Transition. Labour Economics, 39, pp. 68-87.

Lukyanova A.L. (2010) Returns to Education: What Meta-Analysis Reveals. HSE Economic Journal, 14, 3, pp. 326-348.

Mincer J.A. (1974) Schooling, Experience, and Earnings. New York: NBER Books.

Montenegro C.E., Patrinos H.A. (2014) Comparable Estimates of Returns to Schooling around the World. World Bank Policy Research Working Paper no 7020.

Münich D., Svejnar J., Terrell K. (2005) Returns to Human Capital under The Communist Wage Grid and During the Transition to a Market Economy. Review of Economics and Statistics, 87, 1, pp. 100-123.

Muravyev A. (2008) Human Capital Externalities Evidence from the Transition Economy of Russia 1. Economics of Transition, 16, 3, pp. 415-443.

Naikal E., Emelyanova O., Nemova V., Lange G.-M., Sanghi A. (2019) How Wealthy Is Russia? Measuring Russia's Comprehensive Wealth from 2000-2017. World Bank. 
Patrinos H.A. (2016) Estimating the Return to Schooling Using the Mincer Equation. IZA World of Labor.

Patrinos H.A., Sakellariou Ch.N. (2005) Schooling and Labor Market Impacts of a Natural Policy Experiment. Labour, 19, 4, pp. 705-719.

Pons E., Gonzalo M.T. (2001) Returns to Schooling in Spain: How Reliable Are IV Estimates? Working Papers 446, Queen Mary University of London, School of Economics and Finance.

Psacharopoulos G., Patrinos H.A. (2018) Returns to Investment in Education: A Decennial Review of the Global Literature. Education Economics, 26, 5, pp. 445-58.

Rudakov V., Figueiredo H., Teixeira P., Roshchin S. (2019) The Impact of Horizontal Job-Education Mismatches on the Earnings of Recent University Graduates in Russia. IZA Discussion Paper no 12407, Institute for the Study of Labor.

Schultz T.W. (1972) Human Capital: Policy Issues and Research Opportunities. Economic Research: Retrospect and Prospect, Vol. 6, Human Resources. NBER, pp.1-84.

Strumilin S. (1924) Economic Significance of National Education. Planovove Khoziastvo (Planned Economy), 9-10.

Telezhkina M. (2019) Massification of Higher Education System in Russia, July 8-12, WB-HSE Summer School on the Economics of Education, Moscow.

Vernon V. (2002) Returns to Human Capital in Transitional Russia. Department of Economics, The University of Texas at Austin. 